\title{
Nitrogen cycling and bacterial community structure of sinking and aging diatom aggregates
}

\author{
Ann Sofie Birch Lundgaard ${ }^{1, *}$, Alexander H. Treusch ${ }^{1}$, Peter Stief ${ }^{1}$, Bo Thamdrup ${ }^{1}$, \\ Ronnie N. Glud ${ }^{1,2,3}$ \\ ${ }^{1}$ Department of Biology and Nordic Center for Earth Evolution, University of Southern Denmark, 5230 Odense M, Denmark \\ ${ }^{2}$ Scottish Association for Marine Science, Scottish Marine Institute, Oban PA37 1QA, UK \\ ${ }^{3}$ Department of Ocean and Environmental Sciences, Tokyo University of Marine Science and Technology, Tokyo 108-8477, Japan
}

\begin{abstract}
Sinking phycodetrital aggregates can contribute to anaerobic nitrogen turnover as they may represent oxygen-depleted microbial hot spots in otherwise oxygenated waters. However, the dynamics of anaerobic nitrogen cycling during the long descent of aggregates through oxic or hypoxic waters are unknown. Thus, model aggregates prepared from the diatom Skeletonema marinoi were allowed to age for $4 \mathrm{~d}$ at high and low ambient $\mathrm{O}_{2}$ levels $(70$ and $15 \%$ air saturation, respectively), and changes in nitrogen transformations and microbial community structure were followed. At both $\mathrm{O}_{2}$ levels, denitrification and dissimilatory $\mathrm{NO}_{3}{ }^{-}$reduction to $\mathrm{NO}_{2}{ }^{-}$ (DNRN) were the most important processes of aggregate-associated anaerobic nitrogen cycling. However, at $70 \%$ air saturation, rates of anaerobic $\mathrm{N}$ cycling were lower and decayed towards 0 after an early rise, whereas at $15 \%$ air saturation, they remained constantly high at average production rates of $0.66 \mathrm{nmol} \mathrm{N}_{2}-\mathrm{N}$ aggregate (aggr.) $)^{-1} \mathrm{~h}^{-1}$ and $0.26 \mathrm{nmol} \mathrm{NO}_{2}{ }^{-}$aggr. $^{-1} \mathrm{~h}^{-1}$. At both $\mathrm{O}_{2}$ levels, but more pronouncedly at $70 \%$ air saturation, the microbial community underwent succession as expressed by an increase in (1) relative abundance of specific bacterial taxonomic units; (2) bacterial diversity; and (3) prokaryotic abundance. Probably, a higher carbon oxidation rate at high ambient $\mathrm{O}_{2}$ level progressively selected for microbes capable of using complex carbon polymers. Taken together, the occurrence of anoxic aggregate centers may be ephemeral at high ambient $\mathrm{O}_{2}$ levels, but persistent at low ambient $\mathrm{O}_{2}$ levels, indicating that sinking phycodetrital aggregates can remain sinks for bioavailable $\mathrm{N}$ in the oceans for several days, especially in $\mathrm{O}_{2}$-depleted settings.
\end{abstract}

KEY WORDS: Marine snow $\cdot$ Diatom aggregates $\cdot$ Nitrogen cycle $\cdot$ Denitrification $\cdot{ }^{15} \mathrm{~N}$-labeling experiments $\cdot$ Oxygen minimum zone $\cdot$ Molecular community fingerprinting

\section{INTRODUCTION}

Sinking macroscopic aggregates represent an important conduit for transferring organic material and nutrients from the photic zone to deeper waters, and are a ubiquitous feature of most marine settings. However, their formation is particularly intensive at the end of phytoplankton blooms and in polar regions during periods of sea-ice melt, which can lead to mass release of agglutinated sea-ice algae (Smetacek 1985, Boetius et al. 2013, Fernández-

\footnotetext{
${ }^{*}$ Corresponding author: aslundgaard@biology.sdu.dk
}

Méndez et al. 2014, Glud et al. 2014). Although typically dominated by algal material, aggregates also include zooplankton carcasses, protists, fecal pellets, and detrital particles in different stages of decomposition (Silver 2015). 'Marine snow' thus consists of highly diverse microhabitats that sink towards the seabed. The diameter of macroscopic aggregates ranges from $500 \mu \mathrm{m}$ to several centimeters (Simon et al. 2002, Grossart et al. 2003, Glud et al. 2014) and their sinking velocity reaches up to several hundred meters per day, depending on the size and density of

(1) The authors 2017. Open Access under Creative Commons by Attribution Licence. Use, distribution and reproduction are unrestricted. Authors and original publication must be credited. 
the aggregates (Simon et al. 2002, Ziervogel \& Forster 2005, Iversen \& Ploug 2013, Agusti et al. 2015). The sinking aggregates generally exhibit intensified metabolic activity (Ploug \& Grossart 2000, Grossart \& Ploug 2001) and function as metabolic hot spots with microbial densities that are 3 to 4 orders of magnitude larger than in the ambient water (Wörner et al. 2000, Silver 2015, Thiele et al. 2015). The aggregate-associated microbial communities are also typically fundamentally different from those of the surrounding seawater (Alldredge \& Youngbluth 1985, DeLong et al. 1993, Moeseneder et al. 2001).

One important aspect of sinking aggregates is the possibility to form anoxic centers hosting active anaerobic microbial communities. This has been documented for compact fecal pellets (Alldredge \& Cohen 1987), zooplankton carcasses (Glud et al. 2015), cyanobacterial colonies and aggregates (Paerl \& Bebout 1988, Klawonn et al. 2015), and diatom aggregates (Ploug et al. 1997, Ploug \& Bergkvist 2015, Stief et al. 2016). Recent investigations documented denitrification and dissimilative nitrate reduction to ammonia (DNRA) activity in sinking diatom and cyanobacterial aggregates being exposed to low ambient $\mathrm{O}_{2}$ levels $(<40 \%$ air saturation [AS]) (Klawonn et al. 2015, Ploug \& Bergkvist 2015, Stief et al. 2016). Thus, sinking phycodetrital aggregates can potentially play an important role for $\mathrm{N}$ turnover in the pelagic environment, especially if they contain diatoms that have $\mathrm{NO}_{3}{ }^{-}$storing capabilities (Stief et al. 2016, Kamp et al. 2016).

Sinking aggregates are, however, not static microenvironments and their dynamic nature needs to be acknowledged to assess their potential impact on pelagic $\mathrm{N}$ cycling. Availability of labile organic material, nutrients, and $\mathrm{O}_{2}$ will change in response to ongoing metabolic activity, cell lysis, and microbial succession within the aging aggregates. Furthermore, these processes will interrelate with the ambient concentrations of $\mathrm{O}_{2}$ and $\mathrm{NO}_{3}{ }^{-}$, and respond to changes in temperature. The changing internal microenvironment is expected to affect the relative importance and the coupling between $\mathrm{N}$ transformations, such as nitrification, denitrification, and DNRA - and thereby the products of $\mathrm{N}$ processing associated with sinking aggregates. However, investigations of any succession in $\mathrm{N}$ processing and microbial community structure in aging aggregates have not been conducted in detail. To assess the potential importance of sinking aggregates for pelagic $\mathrm{N}$ cycling, it remains to be investigated whether anaerobic $\mathrm{N}$ cycling persists for longer periods or represents only a short incidental period during aggregate descend. The present study aimed to quantify the development in nitrogen turnover of sinking and aging model aggregates dominated by the ubiquitous diatom Skeletonema marinoi. Specific process rates were followed for a total of $4 \mathrm{~d}$ through ${ }^{15} \mathrm{NO}_{3}{ }^{-}$enrichment incubations at 2 different ambient $\mathrm{O}_{2}$ levels. Concurrently, the succession in microbial community size and structure within the aggregates was followed in order to reveal potential links to community metabolism. The combined data were used to evaluate and discuss the potential importance of sinking diatom aggregates for $\mathrm{N}$ turnover in the oceans, with particular emphasis on areas with reduced $\mathrm{O}_{2}$ levels.

\section{MATERIALS AND METHODS}

\section{Production of model aggregates}

Diatom-based aggregates were produced from an axenic culture of the marine diatom Skeletonema marinoi (CCMP1332, NCMA). For aggregate production, culture samples were mixed with unfiltered preconditioned coastal surface seawater collected near Kerteminde, Denmark $\left(55^{\circ} 27^{\prime} 00.5^{\prime \prime} \mathrm{N}, 10^{\circ} 39^{\prime}\right.$ 44.1" E). Preconditioning of the water included raising the in situ salinity from 23 to 30 with $\mathrm{NaCl}$ to match the growth conditions of the $S$. marinoi strain used, and incubation at $15^{\circ} \mathrm{C}$ for $2 \mathrm{wk}$ prior to aggregate production to allow the bacterial community to adapt to the higher salinity.

Aggregate production was initiated by mixing $45 \mathrm{ml}$ of stationary-phase $S$. marinoi culture and $585 \mathrm{ml}$ seawater into gas-tight glass bottles, avoiding entrapment of gas bubbles. In total, 28 bottles were mounted on a plankton wheel with a diameter of $70 \mathrm{~cm}$ rotating at $1.7 \mathrm{rpm}$. The rotating bottles were kept in a $12 \mathrm{~h}$ light:12 $\mathrm{h}$ dark cycle at $15^{\circ} \mathrm{C}$. Visual aggregates appeared within the first hour, and within $3 \mathrm{~d}$, the ellipsoid-shaped aggregates (Fig. 1A,C) had a rather uniform size of 2.2, 1.6, and $1.6 \mathrm{~mm}$ in length, height, and width, respectively, and a volume of $3.1 \mathrm{~mm}^{3} \pm 1.3$ (mean $\pm \mathrm{SE}_{;} \mathrm{n}=48$ ). These freshly formed aggregates were then used for the succession experiment.

\section{Succession experiment}

Intact, similar sized aggregates were carefully transferred from the production bottles to new $0.5 \mathrm{l}$ glass bottles containing seawater, using a glass tube (10 cm long, $0.5 \mathrm{~cm}$ in inner diameter) equipped with 


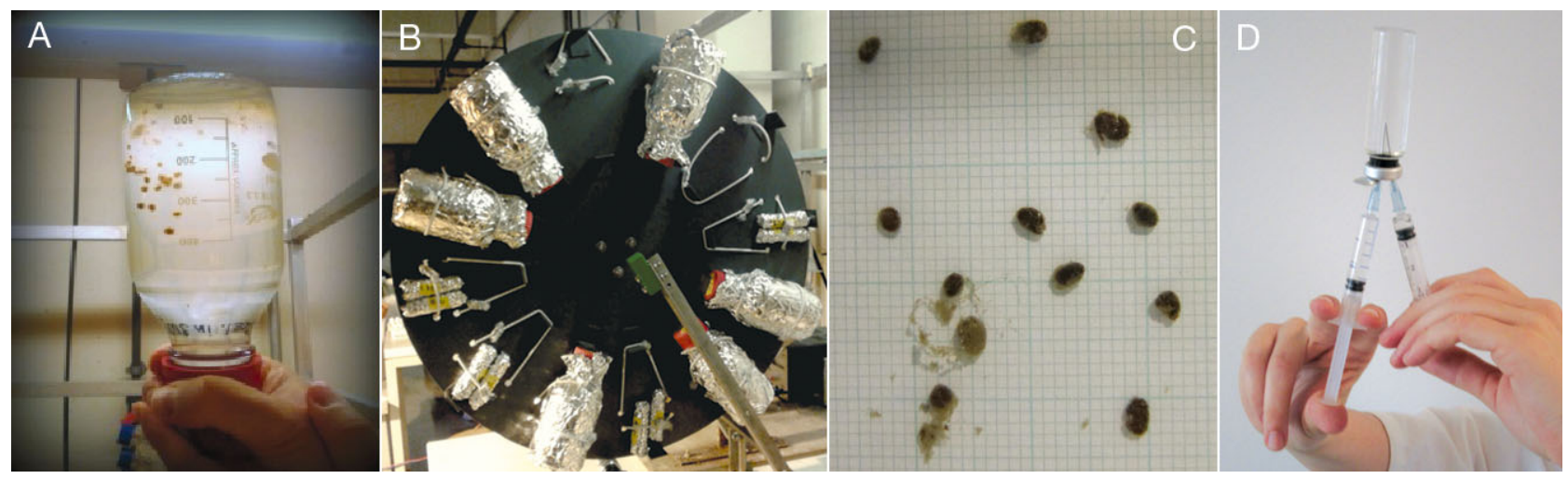

Fig. 1. (A) A production bottle and (B) storage bottles on a plankton wheel with (C) Skeletonema marinoi aggregates. (D) Sampling of water during the short-term ${ }^{15} \mathrm{~N}$-enrichment experiments. One syringe contained ${ }^{15} \mathrm{NO}_{3}{ }^{-}$-enriched replacement water with an $\mathrm{O}_{2}$ concentration that would counteract the concentration drop in the vial, and was injected as the sample water was withdrawn by the empty syringe

a syringe for suction. The seawater was enriched with $\mathrm{NO}_{3}{ }^{-}$to a final concentration of $25 \mu \mathrm{M}$ (comparable to nitrate concentrations in typical deeper, oceanic water) (Anderson et al. 1982, Codispoti et al. 2001). A total of 11 aggregates were transferred to each bottle and 18 bottles were prepared in all. In each incubation bottle, all aggregates came from different production bottles. In total, 9 bottles were adjusted to low $\mathrm{O}_{2}$ conditions (i.e. $15 \% \mathrm{AS}$ ), and 9 bottles were adjusted to high $\mathrm{O}_{2}$ conditions (i.e. $70 \%$ AS) by flushing with $\mathrm{O}_{2}$ and $\mathrm{N}_{2}$ as controlled by a digital gas mixer (Brooks Mass Flow Controller). The closed incubation bottles were incubated on the plankton wheel in darkness at $15^{\circ} \mathrm{C}$ for $4 \mathrm{~d}$ (Fig. 1B). Oxygen concentration was monitored over time with custom-made $\mathrm{O}_{2}$-sensitive fluorescent patches, fixed to the inside of the bottles (Glud et al. 2015). The sensor patches were interrogated from the outside by a FireSting $\mathrm{O}_{2}$ meter (Pyro Science). A large fraction of the seawater was exchanged twice per day to maintain almost constant $\mathrm{O}_{2}$ concentration $( \pm 6$ and $29 \%$ of the set point values in the high and low $\mathrm{O}_{2}$ treatments, respectively) and to renew the natural constituents of the seawater (e.g. dissolved organic carbon [DOC], nutrients, small particles, and bacteria). After $1 \mathrm{~d}$ of incubation (designated $T_{1 \mathrm{~d}}$ ), 6 bottles ( 3 from the low and 3 from the high $\mathrm{O}_{2}$ treatment) were sacrificed for rate measurements of key processes of the nitrogen cycle, characterization of the microbial communities, and enumeration of prokaryote abundance. This was repeated $2\left(T_{2 \mathrm{~d}}\right)$ and $4 \mathrm{~d}$ $\left(T_{4 \mathrm{~d}}\right)$ after initiating the experiment. A common reference point for both oxygen treatments was included by initial sampling of aggregates prior to any $\mathrm{O}_{2}$ treatments $\left(T_{0 \mathrm{~d}}\right)$.

\section{Measurement of $\mathbf{N}$ cycle processes}

\section{Experimental procedure}

The most relevant dissimilatory processes of the nitrogen cycle were measured in short-term $(6 \mathrm{~h}){ }^{15} \mathrm{~N}$ isotope enrichment incubations. At each sampling point (i.e. $T_{0 \mathrm{~d}}, T_{1 \mathrm{~d}}, T_{2 \mathrm{~d}}$, and $T_{4 \mathrm{~d}}$ ), 8 intact aggregates were transferred from each glass bottle ( 3 from the low and 3 from the high $\mathrm{O}_{2}$ treatment) to a $20 \mathrm{ml}$ glass vial filled with seawater and equipped with an oxygen optode patch. The 3 remaining aggregates in each bottle were sampled for microbial community structure. The seawater was enriched with $25 \mu \mathrm{M}$ ${ }^{15} \mathrm{NO}_{3}{ }^{-}$and the $\mathrm{O}_{2}$ AS level was adjusted to 15 or $70 \%$ (corresponding to 39 or $183 \mu \mathrm{M}$, respectively) by flushing with $\mathrm{O}_{2}$ and $\mathrm{He}$ as controlled by a digital gas mixer. For controls, 2 vials without aggregates were incubated in parallel under the same conditions at 15 and $70 \% \mathrm{O}_{2} \mathrm{AS}$, respectively. The background $\mathrm{NO}_{3}^{-}$ concentration in the aged seawater was $3.7 \mu \mathrm{M}$ (corresponding to $13 \%$ of total $\mathrm{NO}_{3}^{-}$after ${ }^{15} \mathrm{NO}_{3}^{-}$addition). The vials were sealed with gas-tight stoppers avoiding entrapment of gas bubbles, and were incubated on the plankton wheel $(1.7 \mathrm{rpm})$ in darkness at $15^{\circ} \mathrm{C}$ for $6 \mathrm{~h}$. After $0,1,2,4$, and $6 \mathrm{~h}, \mathrm{O}_{2}$ was measured and a water sample $(3 \mathrm{ml})$ was taken from each glass vial. On each occasion, the water withdrawn from the glass vial was replaced with ${ }^{15} \mathrm{NO}_{3}^{-}$enriched seawater adjusted to an $\mathrm{O}_{2}$ concentration that would compensate for the drop in $\mathrm{O}_{2}$ concentration since the last sampling point (Fig. 1D). The $3 \mathrm{ml}$ sample was split into the following 2 vials: (1) $1.5 \mathrm{ml}$ was added to $3 \mathrm{ml} \mathrm{He-flushed,} \mathrm{half-evacuated} \mathrm{Exe-}$ tainers (Labco) containing $50 \mu \mathrm{l} \mathrm{ZnCl}_{2}$ (50\%) and 
stored for ${ }^{15} \mathrm{~N}$ analysis; and (2) the remaining $1.5 \mathrm{ml}$ was stored at $-20^{\circ} \mathrm{C}$ for dissolved inorganic nitrogen (DIN) analysis as described by Stief et al. (2016).

\section{Nitrogen analyses}

$\mathrm{NO}_{3}^{-}$and $\mathrm{NO}_{2}^{-}$concentrations were quantified on a NOx analyzer (CLD 66s, Eco Physics) with the $\mathrm{VCl}_{3}$ and NaI reduction assay, respectively (Braman \& Hendrix 1989, Yang et al. 1997). $\mathrm{NH}_{4}{ }^{+}$concentrations were determined with the Na-salicylate method (Bower \& Holm-Hansen 1980) using a spectrophotometer (Multiskan GO Microplate spectrophotometer, Thermo Scientific). Isotopically labeled nitrogen species ${ }^{15} \mathrm{~N}-\mathrm{N}_{2}\left({ }^{29} \mathrm{~N}_{2}+{ }^{30} \mathrm{~N}_{2}\right),{ }^{15} \mathrm{NO}_{2}{ }^{-}$, and ${ }^{15} \mathrm{NH}_{4}{ }^{+}$were analyzed on a gas chromatography-isotopic ratio mass spectrometer (GC-IRMS; Thermo Delta V Plus, Thermo Scientific) (Dalsgaard et al. 2012). The samples for $\mathrm{N}_{2}$ analysis were withdrawn from the headspace of the $3 \mathrm{ml}$ Exetainers, while ${ }^{15} \mathrm{~N}$-labeling of $\mathrm{NO}_{2}{ }^{-}$and $\mathrm{NH}_{4}{ }^{+}$was analyzed with the sulfamic acid and the hypobromite assay, respectively, followed by measurement of ${ }^{15} \mathrm{~N}-\mathrm{N}_{2}$ (Warembourg 1993, McIlvin \& Altabet 2005, Stief et al. 2016). Accumulation of ${ }^{15} \mathrm{~N}_{2} \mathrm{O}$ was not detected in any of the incubations.

\section{Aggregate characterization}

For quantification of the $\mathrm{C}: \mathrm{N}$ ratio, aggregates (from short-term incubations at $T_{0 \mathrm{~d}}$ ) were filtered (with deionized water) onto pre-weighed, combusted $25 \mathrm{~mm}$ GF/F filters. The filter-samples were dried for $2 \mathrm{~d}$ at $60^{\circ} \mathrm{C}$ and analyzed on a Carlo-Erba CHN analyzer. The sinking speeds of 19 aggregates from another batch of aggregates with similar dimensions were visually determined in a sedimentation column (mean diameter $[\varnothing]=2.7 \mathrm{~cm}$ ) at $14^{\circ} \mathrm{C}$ and salinity of 30. The excess density at the experimental conditions was calculated from the sinking speeds using the Navier-Stokes drag equation according to Iversen \& Ploug (2010).

Rate calculations and statistics

The rate of solute production and consumption was calculated from linear regression of concentration changes during the incubations, accounting for any dilution during the sampling process. As the rates measured in the water with aggregates included any activity from the free-living microbial community, the control rates were subtracted to derive the aggregate-specific rates of the respective solutes.

The slope of each replicate and the mean slopes were analyzed with $t$-tests (2-tailed and 1-tailed, respectively) to test whether they were significantly different from 0 . The effect of time on the same variables in either the high or low $\mathrm{O}_{2}$ treatment was tested with ANOVA (1-way) and Tukey post hoc tests were performed in $\mathrm{R}$ ( $\mathrm{R}$ core team, version 3.1.2). The effect of time was further tested by plotting the replicate rates with time $(4 \mathrm{~d})$ and analyzing the regressions with $t$-tests (2-way).

The production/consumption of $\mathrm{N}$ compounds was integrated over the $4 \mathrm{~d}$ of aging to derive a timeintegrated turnover, and standard error was calculated according to the rules of error propagation. The effect of $\mathrm{O}_{2}$ on the time-integrated turnover was tested with $t$-tests (2-tailed). The total $\mathrm{N}_{2}$ produced from denitrification was calculated using the relation between the ${ }^{29} \mathrm{~N}_{2}$ and ${ }^{30} \mathrm{~N}_{2}$ production rates, assuming random isotope pairing. The calculations accounted not only for the background ${ }^{14} \mathrm{NO}_{3}{ }^{-}$, but also for other possible sources of ${ }^{14} \mathrm{NO}_{3}{ }^{-}$, for example from nitrification and leakage of intracellular nitrate from S. marinoi (Kamp et al. 2011, Stief et al. 2016).

\section{Microbial community analysis}

\section{Enumeration of prokaryotes}

Immediately after the short-term incubations, aggregate samples for prokaryotic abundance were disintegrated to detach aggregate-associated prokaryotes. The aggregates were exposed to ultra-sonication (Branson 2200, $60 \mathrm{~W}, 160 \mathrm{~s}$ ) in $0.025 \mathrm{mM}$ tetrasodium pyrophosphate fixed with paraformaldehyde to $2 \%$ final concentration (Velji \& Albright 1986, Schramm et al. 1998), and stored at $4^{\circ} \mathrm{C}$ until enumeration. For counting prokaryotes, the preserved samples (in triplicates) were diluted and filtered onto $0.2 \mu \mathrm{m} \mathrm{Nu}-$ clepore track-etched membranes (Whatman, GE Healthcare) followed by staining with 4', 6-diamidino2-phenylindole (DAPI). The prokaryotes were hereafter visualized with an epifluorescence microscope where 10 fields of view were counted for each sample (to include $>500$ cells in each count).

DNA extraction and bacterial community profiling

From each oxygen treatment and respective sampling points, 3 aggregates were pooled into UV- 
sterilized cryo vials, and were immediately frozen in liquid nitrogen before being stored at $-80^{\circ} \mathrm{C}$ until DNA extraction. The aged seawater, the seawater from the aggregate production bottles, and the seawater from the succession experiment were filtered (0.5 l) onto sterile $0.2 \mu \mathrm{m}$ Supor 200 polyethersulfone membranes (Pall Corporation, Life Sciences) and stored like the aggregate samples. The DNA extractions from the aggregate and the water samples were performed using the PowerLyzer PowerSoil DNA Isolation Kit and the PowerWater DNA Isolation Kit, respectively (both MO BIO), following the manufacturer's protocol. The DNA was quantified with a fluorometer with the Quant-iT PicoGreen Kit (Invitrogen), providing average yields of 5.1 and $32.3 \mathrm{ng}^{-1} \mathrm{l}^{-1}$ in the solution for aggregates and water, respectively.

To profile the bacterial community with terminal restriction length polymorphism (T-RFLP) analysis (Liu et al. 1997), the genes encoding bacterial 16S rRNA were amplified with PCR using the phosphoramidite fluorochrome 5-carboxyfluorescein labeled forward primer B27FAM (50-AGR GTT YGA TYM TGG CTC AG-30) and the reverse primer U519R (50GWA TTA CCG CGG CKG CTG-30). PCR was performed in $50 \mu \mathrm{l}$ reactions with final amounts of 5 to $10 \mathrm{ng}$ template, $20 \mathrm{pmol}$ of each primer, $10 \mathrm{nmol}$ deoxynucleoside triphosphates in equal amounts, $5 \mu \mathrm{l}$ 10X Taq buffer with $\left(\mathrm{NH}_{4}\right)_{2} \mathrm{SO}_{4}, 1.25$ units Taq

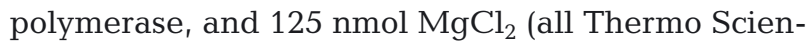
tific). Denaturation at $94^{\circ} \mathrm{C}$ for 2 min was followed by 32 cycles of $94^{\circ} \mathrm{C}$ for $20 \mathrm{~s}, 54^{\circ} \mathrm{C}$ for $45 \mathrm{~s}$, and $72^{\circ} \mathrm{C}$ for $45 \mathrm{~s}$, with a final elongation step of $5 \mathrm{~min}$ at $72^{\circ} \mathrm{C}$. Successful amplification was verified by agarose gel electrophoresis using $1.5 \%$ gels. The $\sim 500 \mathrm{bp}$ PCR product was incubated with $5 \mathrm{U}$ of the restriction enzyme BsuRI in buffer R (Thermo Scientific) at $37^{\circ} \mathrm{C}$ for $12 \mathrm{~h}$, followed by heat inactivation at $80^{\circ} \mathrm{C}$ for $20 \mathrm{~min}$. Resulting restriction fragments were purified with the GeneJET PCR purification kit (Thermo Scientific). The average DNA yield after PCR, restriction, and purification was $4.2 \mathrm{ng}^{-1} \mathrm{l}^{-1}$. Finally, the processed DNA ( 100 ng) was analyzed with capillary electrophoresis at the Uppsala Genome Center in Sweden.

Bioinformatics analysis of the microbial community profiles

For sizing, the T-RFLP data were analyzed with the Peak Scanner software (Applied Biosystems). Noise filtration, clustering, and construction of data matrices were performed with the online program T-RFLP analysis EXpedited (http://trex.biohpc.org/) with a noise filtration factor of 1.2 based on the peak area, and a clustering threshold factor of 0.5 . The operational taxonomic unit (OTU) fluorescence was standardized to the total fluorescence of all OTUs in a sample, and matrices of different sample combinations of interest were created. For each of these matrices, only OTUs with a relative abundance above $0.5 \%$ and those present in more than 1 sample were analyzed. The data matrices were analyzed with $\mathrm{R}(\mathrm{R}$ core team, version 3.1.2) and the $R$ package vegan (Oksanen et al. 2013), where the dissimilarities between samples and their respective OTUs were calculated and visualized with non-metric multidimensional scaling (NMDS). The function metaMDS was used to find the best fit between Bray-Curtis dissimilarities and ordinations with minimal stress (goodness of fit). Owing to a large range, the data values were square-root transformed, and then submitted to Wisconsin double standardization. The function found species scores as weighted averages of site scores, but expanded them so that species and site scores had equal variances (Oksanen et al. 2013). All NMDS settled for 2 dimensions and low stress ranging from 0.06 to 0.1 , also evaluated with Shepard plots. Relevant environmental data were fitted onto the ordination with the function envfit, where the projection of points has maximum correlation with corresponding environmental variables (Oksanen et al. 2013). Analysis of similarities (ANOSIM) was used to test statistically whether there was a significant difference between sample groups of interest (Oksanen et al. 2013).

\section{RESULTS}

\section{Aggregate characteristics}

During aggregate formation, the $\mathrm{O}_{2}$ concentration in the production bottles increased during daytime to $\sim 110 \%$ AS. Hence, $\mathrm{O}_{2}$ production by the viable diatoms exceeded $\mathrm{O}_{2}$ consumption by microbial respiration under light conditions. However, during the $4 \mathrm{~d}$ succession experiment in darkness, the $\mathrm{O}_{2}$ concentration declined, and water was exchanged twice a day to maintain stable $\mathrm{O}_{2}$ concentrations in the bottles, with means of $17.8 \pm 0.6$ and $67.3 \pm 0.6 \%$ AS (mean $\pm \mathrm{SE}, \mathrm{n}=65$ ) in the low and high $\mathrm{O}_{2}$ treatments, respectively. No measurable change in aggregate size during the incubation was detected, and the ellipsoidal aggregates maintained the average diameters of $2.2 \pm 0.1,1.6 \pm 0.1$, and $1.6 \pm 0.1 \mathrm{~mm}$ corresponding to a volume of $3.1 \pm 0.2 \mathrm{~mm}^{3}(\mathrm{n}=45)$. The 
average molar $\mathrm{C}: \mathrm{N}$ ratio of the aggregates was $7.3 \pm$ $0.2(\mathrm{n}=5)$ and the average sinking speed of the aggregates amounted to $374 \pm 28 \mathrm{~m} \mathrm{~d}^{-1}(\mathrm{n}=19)$, which equates to an excess density of $2.6 \mu \mathrm{g} \mathrm{cm}^{-3}$.

\section{Aggregate-associated $\mathrm{O}_{2}$ respiration and $\mathrm{N}$ cycling}

The metabolic activity of the aggregates was quantified at 4 time points during the $4 \mathrm{~d}$ succession experiment. Generally, the solute concentrations changed linearly over the $6 \mathrm{~h}$ incubations (after correction for dilution during sampling) (Fig. 2; see Fig. S1 in the Supplement at www.int-res.com/ articles/suppl/a079p085_supp.pdf). Only in a few instances did the solute concentration change nonlinearly, e.g. the $\mathrm{N}_{2}$ production in the low $\mathrm{O}_{2}$ treatment accelerated towards the end of the $T_{0 \mathrm{~d}}$ incubation (Fig. 2B). This was probably due to the transfer of aggregates directly from the production bottles kept at $\sim 100 \% \mathrm{O}_{2}$ AS to the incubation bottles with $15 \%$

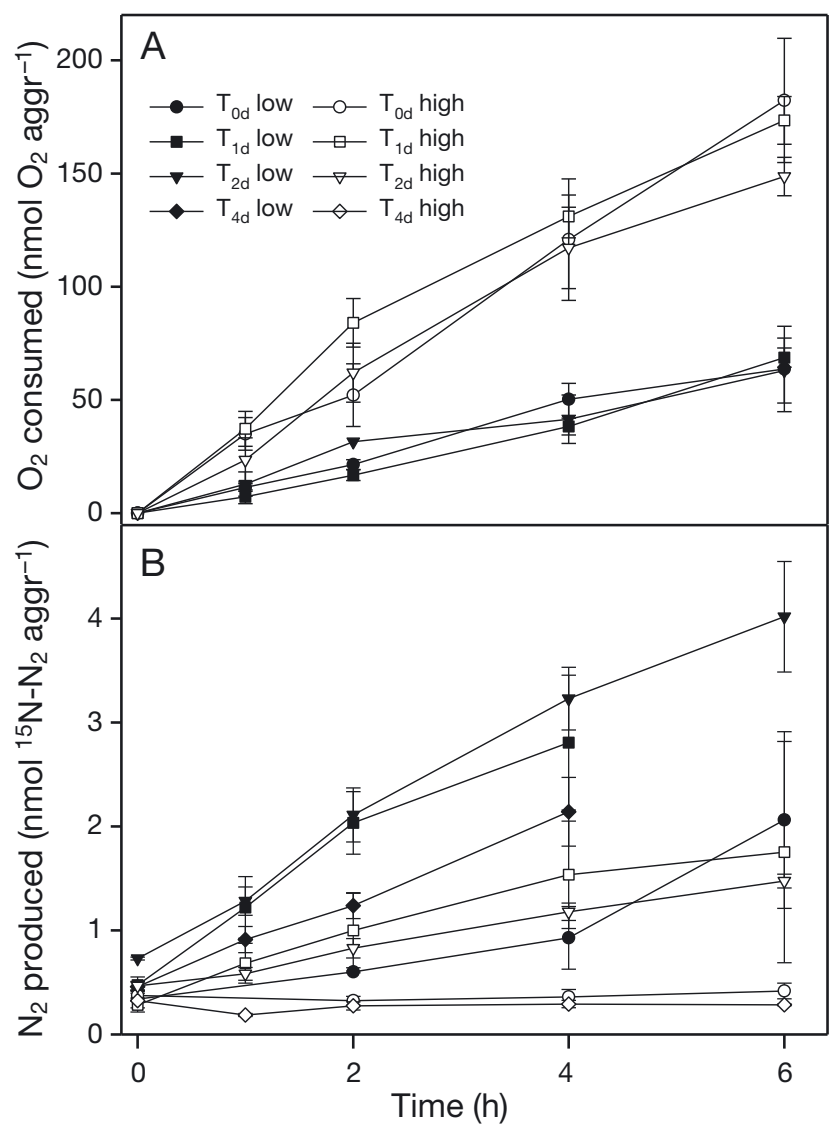

Fig. 2. Time series (mean $\pm \mathrm{SE}, \mathrm{n}=3$ ) of $(\mathrm{A})$ the $\mathrm{O}_{2}$ consumed and (B) the ${ }^{15} \mathrm{~N}-\mathrm{N}_{2}$ produced by sinking Skeletonema marinoi aggregates during short-term incubations at either $15 \%$ (low) or $70 \%$ (high) $\mathrm{O}_{2}$ AS at $T_{0 \mathrm{~d}}, T_{1 \mathrm{~d}}, T_{2 \mathrm{~d}}$, and $T_{4 \mathrm{~d}}$. Owing to technical problems, there are no $\mathrm{O}_{2}$ data available for Day 4
$\mathrm{O}_{2}$ AS, which must have reduced the internal $\mathrm{O}_{2}$ availability. However, active denitrification might have to await production of required enzymes and thus exhibit a lag phase. Remarkably, there was no statistical significant change in the consumption rates of $\mathrm{O}_{2}$ during the $2 \mathrm{~d}$ study period $\left(\mathrm{O}_{2}\right.$ data for Day 4 are missing due to instrument failure), or $\mathrm{NO}_{3}{ }^{-}$ during the $4 \mathrm{~d}$ study period, in either of the 2 treatments. The $\mathrm{O}_{2}$ respiration rate measured in seawater without aggregates (i.e. in control incubations) corresponded to $48 \pm 1.2$ and $40 \pm 12 \%$ of the total $\mathrm{O}_{2}$ respiration rate in the high and low $\mathrm{O}_{2}$ treatment with aggregates, respectively. This corresponds to a 1000fold lower volume-specific activity in the water as compared to the aggregate. On average, aggregates consumed $10.4 \pm 0.1 \mathrm{nmol} \mathrm{O}_{2}$ aggr. $^{-1} \mathrm{~h}^{-1}(\mathrm{n}=12)$ in the low $\mathrm{O}_{2}$ treatment. This was less than half the consumption of $28.7 \pm 0.2 \mathrm{nmol}$ aggr. ${ }^{-1} \mathrm{~h}^{-1}$ in the high $\mathrm{O}_{2}$ treatment (Fig. 3A). The difference presumably reflects the different oxic volumes of the aggregates in the respective treatments. Concurrently, the average nitrate consumption rates over the $4 \mathrm{~d}$ were 1.15 \pm 0.02 and $0.31 \pm 0.02 \mathrm{nmol} \mathrm{N}$ aggr. ${ }^{-1} \mathrm{~h}^{-1}$ in the low and the high $\mathrm{O}_{2}$ treatments, respectively (Fig. 3B), while control incubations without aggregates exhibited no significant change in the ambient $\mathrm{NO}_{3}{ }^{-}$concentrations (not shown).

Nitrite and $\mathrm{N}_{2}$ were produced from $\mathrm{NO}_{3}{ }^{-}$reduction in most incubations (Fig. 3C,D). In the low $\mathrm{O}_{2}$ treatment, the production rate of the reduced nitrogen compounds remained fairly constant throughout the study period (Fig. 3C,D, Table S2), with average values of $0.26 \pm 0.003$ and $0.66 \pm 0.01 \mathrm{nmol} \mathrm{N}$ aggr. ${ }^{-1} \mathrm{~h}^{-1}$ for $\mathrm{NO}_{2}^{-}$and $\mathrm{N}_{2}$, respectively (Fig. 3C,D). In contrast, the high $\mathrm{O}_{2}$ treatment exhibited a maximum in $\mathrm{N}_{2}$ and $\mathrm{NO}_{2}{ }^{-}$production at $T_{1 \mathrm{~d}}$, followed by a statistically significant gradual decline towards 0 at the end of the experiment (Fig. 3C,D). The maximum rates amounted to $0.09 \pm 0.04$ and $0.37 \pm 0.12 \mathrm{nmol} \mathrm{N}$ aggr. ${ }^{-1} \mathrm{~h}^{-1}$ for $\mathrm{NO}_{2}{ }^{-}$and $\mathrm{N}_{2}$, respectively; however, they were still markedly lower than those encountered during the low $\mathrm{O}_{2}$ treatments (Fig. 3C,D, Tables $\mathrm{S} 1 \& \mathrm{~S} 2$ ). The ${ }^{15} \mathrm{NH}_{4}^{+}$accumulation rate was in the very low range $\left(<\right.$ pmol aggr. $\left.{ }^{-1} \mathrm{~h}^{-1}\right)$ and the total $\mathrm{NH}_{4}{ }^{+}$concentrations remained below the detection limit of $0.4 \mu \mathrm{M}$ of the salicylate method (Kempers \& Kok 1989), indicating only insignificant DNRA activity in the investigated aggregates. No ${ }^{15} \mathrm{~N}-\mathrm{N}_{2} \mathrm{O}$ production was detected in any incubations (detection limit $\sim 0.2 \mathrm{nM} \mathrm{N}$ aggr. ${ }^{-1} \mathrm{~h}^{-1}$ ).

To overcome any bias introduced during aggregate production, we selected aggregates from different production bottles and pooled 8 in each incubation. However, parallel incubations still exhibited consid- 


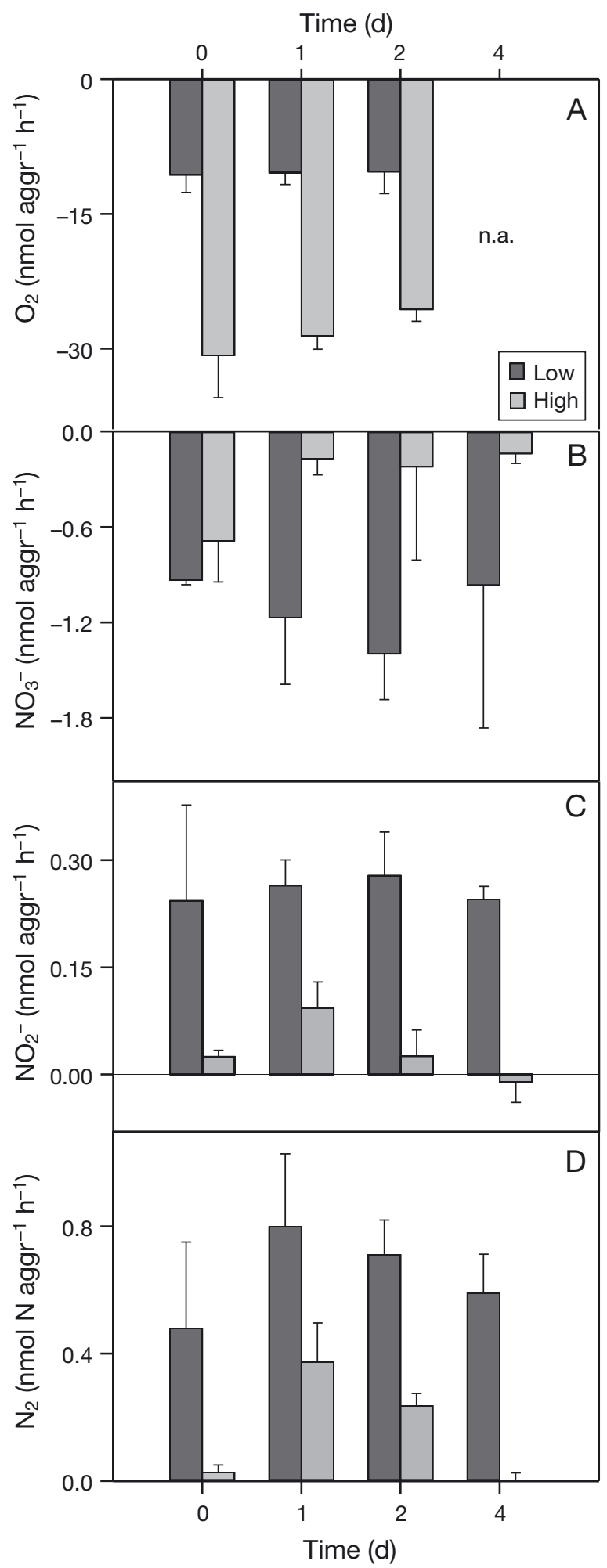

Fig. 3. Aggregate-specific rates (mean $\pm \mathrm{SE}, \mathrm{n}=3$ ) of (A) $\mathrm{O}_{2}$, (B) $\mathrm{NO}_{3}^{-}$, (C) $\mathrm{NO}_{2}^{-}$, and (D) $\mathrm{N}_{2}$ of sinking Skeletonema marinoi aggregates at $15 \%$ (Low) and $70 \%$ (High) $\mathrm{O}_{2}$ AS during a $4 \mathrm{~d}$ period. Positive and negative rates correspond to production and consumption, respectively. Owing to technical problems, there are no $\mathrm{O}_{2}$ data available (n.a.) for Day 4 erable variations, reflecting relatively high heterogeneity among aggregates. For instance, in the high $\mathrm{O}_{2}$ treatment, at $T_{1 \mathrm{~d}}$, each replicate exhibited statistically significant total $\mathrm{N}_{2}$ production $(0.09,0.37$, and $0.32 \mathrm{nmol} \mathrm{N}$ aggr. $^{-1} \mathrm{~h}^{-1}$ ), but the mean of the 3 was not significantly different from 0 . Only at $T_{2 \mathrm{~d}}$ was the average value significantly different from $0\left(\mathrm{~N}_{2}\right.$ total: $0.24 \pm 0.04 \mathrm{nmol} \mathrm{N}$ aggr. $^{-1} \mathrm{~h}^{-1}$ ) (Table S1). In the low $\mathrm{O}_{2}$ treatment, the means of $\mathrm{N}_{2}$ total production were significantly different from 0 in all instances, with the exception of $T_{0 \mathrm{~d}}$. Thus, the data confirm $\mathrm{N}_{2}$ production in aggregates in both $\mathrm{O}_{2}$ treatments, but with highly variable rates between different incubations. The production ratio of ${ }^{29} \mathrm{~N}_{2}\left({ }^{14} \mathrm{~N}^{15} \mathrm{~N}\right)$ and ${ }^{30} \mathrm{~N}_{2}$ $\left({ }^{15} \mathrm{~N}^{15} \mathrm{~N}\right)$ was slightly higher than predicted from the ${ }^{15} \mathrm{~N}$ labeling fraction of $\mathrm{NO}_{3}{ }^{-}$, and ${ }^{28} \mathrm{~N}_{2}\left({ }^{14} \mathrm{~N}^{14} \mathrm{~N}\right)$ was estimated to account for 21 to $31 \%$ of total $\mathrm{N}_{2}$ production assuming random isotope paring (Nielsen 1992, Stief et al. 2016). Thus, $87 \pm 9$ and $92 \pm 10 \%$ of the ${ }^{14} \mathrm{~N}-\mathrm{N}_{2}$ production could be explained from the ${ }^{14} \mathrm{NO}_{3}{ }^{-}$background in the seawater in the low and the high $\mathrm{O}_{2}$ treatments, respectively, based on the isotopes pairing calculations in $\mathrm{N}_{2}$.

\section{Time-integrated $\mathrm{O}_{2}$ and $\mathrm{N}$ turnover}

The time-integrated $\mathrm{O}_{2}$ consumption in the high $\mathrm{O}_{2}$ treatment was $\sim 3$ times higher than in the low $\mathrm{O}_{2}$ treatment, while the consumption of $\mathrm{NO}_{3}{ }^{-}$was $\sim 4$ times higher in the low $\mathrm{O}_{2}$ treatment. Correspondingly, the time-integrated productions of $\mathrm{NO}_{2}^{-}$and $\mathrm{N}_{2}$ were $\sim 8$ and $\sim 4$ times higher in the low $\mathrm{O}_{2}$ treatment, respectively (Fig. 4). The effect of ambient $\mathrm{O}_{2}$ was statistically significant for consumption rates of $\mathrm{NO}_{3}{ }^{-}$, and production rates of $\mathrm{NO}_{2}^{-}$and $\mathrm{N}_{2}$ (Table $\mathrm{S} 2$ ). This strongly indicates a regulatory role of the ambient $\mathrm{O}_{2}$ levels for the interior microbial mediated processes and pathways within the aggregates. The $\mathrm{N}$ budget was not completely closed, as 20 and $11 \%$ of total $\mathrm{NO}_{3}{ }^{-}$consumption was not balanced by the concurrent production of $\mathrm{NO}_{2}{ }^{-}$ and $\mathrm{N}_{2}$ in the low and high $\mathrm{O}_{2}$ treatments, respectively (Fig. 4). The difference could partly be related to $\mathrm{N}$ assimilation by the fast-growing aggregateassociated microbes.

\section{Prokaryotic abundance and bacterial community structure}

The abundance of aggregate-associated prokaryotes increased with an initial doubling time of $25 \mathrm{~h}$ in 


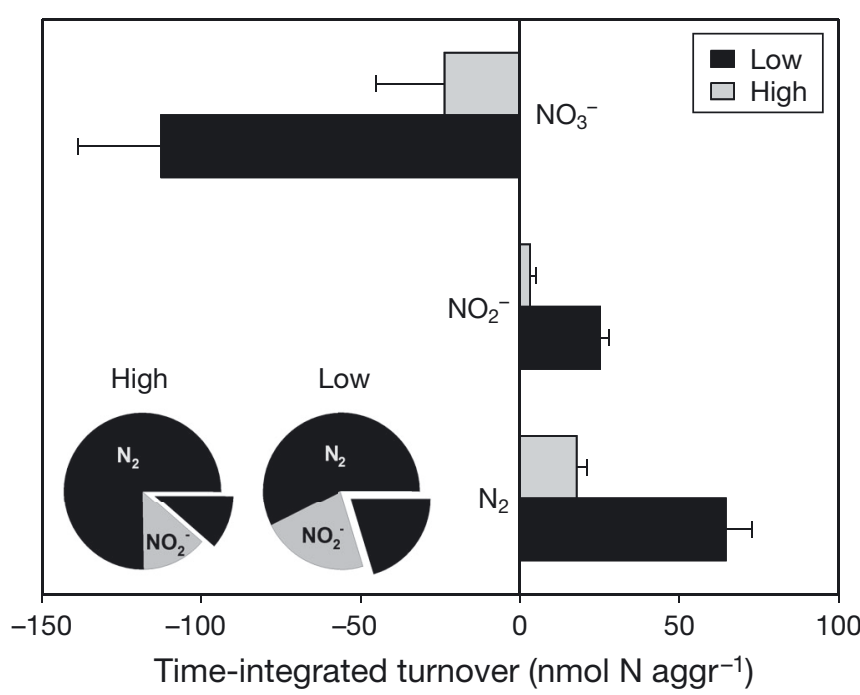

Fig. 4. Aggregate-specific, time-integrated turnover (mean $\pm \mathrm{SE}, \mathrm{n}=3$, time $=4 \mathrm{~d}$ ) of $\mathrm{NO}_{3}{ }^{-}, \mathrm{NO}_{2}{ }^{-}$, and $\mathrm{N}_{2}$ from sinking Skeletonema marinoi aggregates at $15 \%$ (Low) and $70 \%$ (High) $\mathrm{O}_{2}$ AS. Positive and negative rates correspond to production and consumption, respectively. The percentage turnover of $\mathrm{NO}_{3}{ }^{-}$to $\mathrm{NO}_{2}{ }^{-}$and $\mathrm{N}_{2}$ is depicted in a pie chart for low and high ambient $\mathrm{O}_{2}$ levels. The 'detached' piece represents the $\mathrm{NO}_{3}^{-}$not retrieved as any of the measured $\mathrm{N}$ species

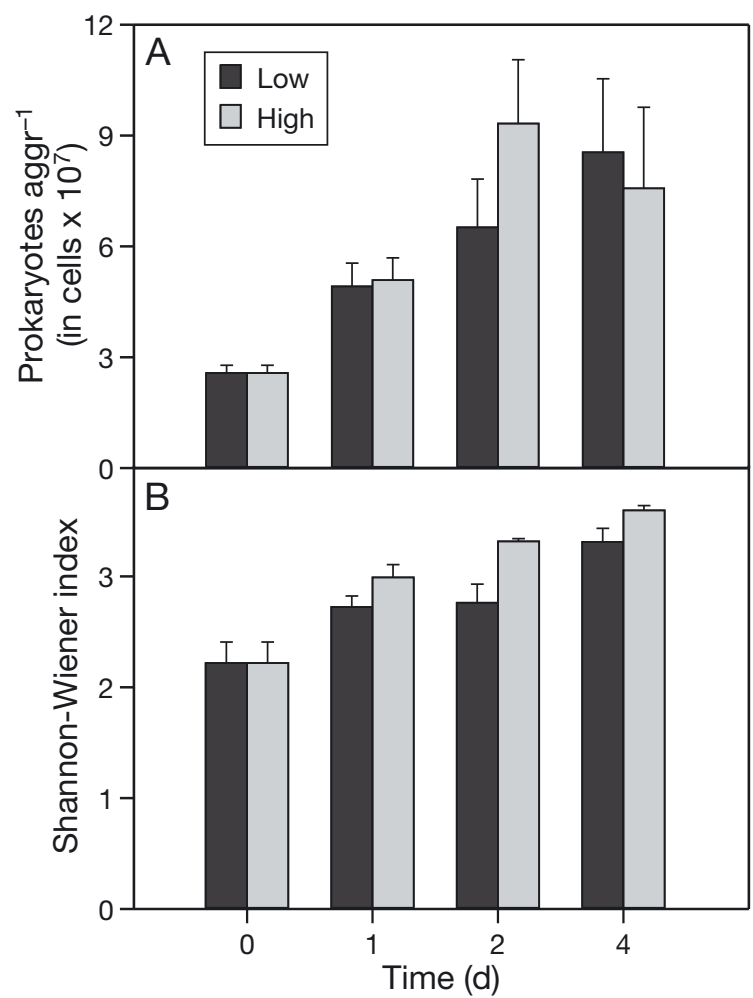

Fig. 5. (A) Skeletonema marinoi aggregate-associated prokaryote abundance per aggregate (mean $\pm \mathrm{SE}, \mathrm{n}=3$ ) at $15 \%$ (Low) and $70 \%$ (High) $\mathrm{AS} \mathrm{O}_{2}$ levels during 4 d. (B) ShannonWiener index representing the diversity of the aggregateassociated bacterial communities as derived from the same incubations both $\mathrm{O}_{2}$ treatments, and overall, the prokaryotic abundance in the 2 treatments increased approximately 3 -fold during the $4 \mathrm{~d}$ of the succession experiment (Fig. 5A). The diversity of the bacterial community at the different time points was assessed with the Shannon-Wiener index using the T-RFLP data (Fig. 5B). In the high $\mathrm{O}_{2}$ treatment, diversity increased gradually as expressed by a significant difference between subsequent time points (Table S2). This was not as distinct in the low $\mathrm{O}_{2}$ treatment, where subsequent time points were not significantly different, but the diversity still increased significantly from $T_{0 \mathrm{~d}}$ to $T_{4 \mathrm{~d}}$. (Fig. 5B, Table S2).

The dissimilarity of the bacterial communities between the samples was assessed with an NMDS analysis of the T-RFLP data. All 4 NMDS plots have low stress values of $0.10,0.06,0.06$, and 0.07 (Fig. 6), indicating a high quality of the plots, but also that the bacterial communities were similar between samples (Quinn \& Keough 2002). When plotting all data together (Fig. 6A), the microbial communities clustered into the following 4 groups: aggregates; natural seawater (aged); seawater from the aggregate production; and seawater from the incubations. Replicates clustered closely together, confirming homogeneity in bacterial community composition between replicates. The similarities between the 2 main clusters (seawater vs. aggregates) were assessed with ANOSIM and the significant R-score for the grouping of aggregates vs. seawater was 0.74 , indicating that the 2 clusters were indeed different (Table 1). Together with the results of the control incubations, this indicates that the aggregate-associated processes were mainly driven by aggregate-specific bacterial communities and not by the communities originally found in the seawater. With respect to R-score and grouping in the 2 different $\mathrm{O}_{2}$ treatments, time had a stronger influence at high $\mathrm{O}_{2}$ compared to the low $\mathrm{O}_{2}$ treatment, as indicated by R-scores of 0.72 and 0.39 , respectively (Table 1, Fig. 6B,C). Furthermore, the directions of the time, diversity, and abundance vectors are roughly similar for both treatments (all vectors are significant, $\mathrm{p}<0.05$; Fig. 6B,C). When aggregates from the high and low $\mathrm{O}_{2}$ treatments are analyzed together, it is evident from both the NMDS plot and ANOSIM that time was a strong influential factor (R-score $=0.41$ ) with respect to the clustering of the microbial communities (Table 1, Fig. 6D). On the contrary, the R-score for grouping by the ambient $\mathrm{O}_{2}$ concentration (low vs. high $\mathrm{O}_{2}$ ) was negative and not significant, but when time was additionally taken into account (low $\mathrm{O}_{2} T_{1 \mathrm{~d}}$, high $\mathrm{O}_{2} T_{1 \mathrm{~d}}$, low $\mathrm{O}_{2} T_{2 \mathrm{~d}}$, etc.), the R-score of 0.59 was significant (Table 1, Fig. 6D). 


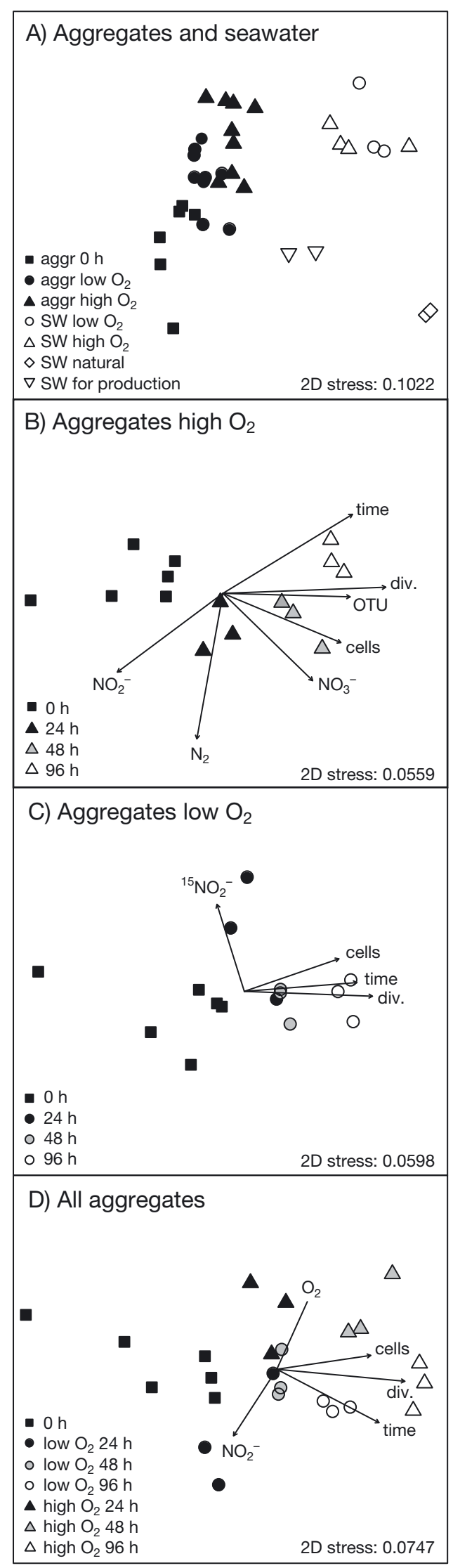

Fig. 6. Multivariate statistical analysis of microbial community structure based on terminal restriction fragment length polymophism (T-RFLP) data. (A) Dissimilarities between aggregates and seawater (SW), aging aggregates (time $=4 \mathrm{~d}$ ) in (B) $70 \%$ (high) $\mathrm{O}_{2} \mathrm{AS}$, or (C) $15 \%$ (low) $\mathrm{O}_{2}$ AS. (D) All aggregates were analyzed with the Bray-Curtis index and plotted with NMDS. The plots were overlaid with vectors for environmental parameters (div., diversity; cells, prokaryotic abundance). Only vectors with $\mathrm{p}<0.05$ are shown. 2D stresses are shown

The temporal development in the microbial communities in both treatments was also evidenced by shifts in relative abundances of OTUs during the course of the experiment (Fig. 7). Specific OTUs generally exhibited similar dynamics among replicates, as can be observed in the heat map of Fig. S2. Overall, we observed a total of 82 aggregate-associated OTUs where 9 new OTUs appeared during the experiment. Most OTUs exhibited similar dynamics in the 2 parallel $\mathrm{O}_{2}$ treatments. However, 15 and 11 OTUs (of which 10 were shared) increased more than 10 -fold in relative abundance over the $4 \mathrm{~d}$ in the high and low $\mathrm{O}_{2}$ treatments, respectively, while 14 and 6 OTUs (of which 3 were shared) concurrently were reduced to $1 / 10$ or less in relative abundance. Of those, 8 and 5 were completely lost in the high and low $\mathrm{O}_{2}$ treatments, respectively (Fig. 7), and consequently 65 and 68 OTUs, respectively, persisted throughout the incubations. Overall shifts in community structure as expressed by an extreme increase or decrease in relative abundance of given OTUs were thus most explicit in the high $\mathrm{O}_{2}$ treatment.

\section{DISCUSSION}

\section{Aggregate-associated $\mathrm{O}_{2}$ and $\mathrm{NO}_{3}{ }^{-}$respiration}

The $\mathrm{O}_{2}$ and $\mathrm{NO}_{3}{ }^{-}$consumption rates of the aging diatom aggregates remained constant during the $4 \mathrm{~d}$ investigation. Previous studies demonstrate how exoand ectoenzymes of the aggregate-associated bacteria hydrolyze the particulate organic carbon (POC), maintaining a high internal concentration of DOC (Azam et al. 1990, Smith et al. 1992). DOC is then subject to further microbial degradation or might be lost to the ambient seawater. Studies on phycodetrital aggregates suggest that 40 to $50 \%$ of the initial POC content is lost during a period of 3 to $6 \mathrm{~d}$ (Ploug \& Grossart 2000, Grossart \& Ploug 2001), and the decomposition rate of 0.6 to $0.9 \mu \mathrm{mol} \mathrm{d}^{-1}$ of aggregate-associated POC would lead to an estimated total 
Table 1. ANOSIM (NMDS statistics) showing the R-score and the associated p-value for each grouping of the bacterial communities of either Skeletonema marinoi aggregates or seawater. Aggr., aggregates; SW, seawater; nat. SW, natural seawater; prod., production; incub., incubation; ns, not significant

\begin{tabular}{|c|c|c|c|c|}
\hline Samples & Grouping & Categories & $\mathrm{R}$ & $\mathrm{p}$ \\
\hline Aggr. + SW & Aggr. or SW & Aggr., SW & 0.6559 & 0.001 \\
\hline Aggr. + SW & Aggr. or SW & Aggr., nat. SW, SW from aggr. prod., SW from incub. & 0.7377 & 0.001 \\
\hline Aggr. - low & Time & $T_{0 \mathrm{~d}}, T_{1 \mathrm{~d}}, T_{2 \mathrm{~d}}$, and $T_{4 \mathrm{~d}}$ & 0.3591 & 0.005 \\
\hline Aggr. - high & Time & $T_{0 \mathrm{~d}}, T_{1 \mathrm{~d}}, T_{2 \mathrm{~d}}$, and $T_{4 \mathrm{~d}}$ & 0.716 & 0.001 \\
\hline Aggr. & $\mathrm{O}_{2}$ & Low and high & ns & ns \\
\hline Aggr. & Time & $T_{0 \mathrm{~d}}, T_{1 \mathrm{~d}}, T_{2 \mathrm{~d}}$, and $T_{4 \mathrm{~d}}$ & 0.414 & 0.001 \\
\hline Aggr. & $\mathrm{O}_{2}+$ time & $\begin{array}{l}\text { Low }+T_{0 \mathrm{~d}} \text {, low }+T_{1 \mathrm{~d},} \text { low }+T_{2 \mathrm{~d},} \text { low }+T_{4 \mathrm{~d} \text { ' }} \\
\text { High }+T_{0 \mathrm{~d},} \text {, high }+T_{1 \mathrm{~d},} \text {, high }+T_{2 \mathrm{~d},} \text { and high }+T_{4 \mathrm{~d}}\end{array}$ & 0.5937 & 0.001 \\
\hline
\end{tabular}

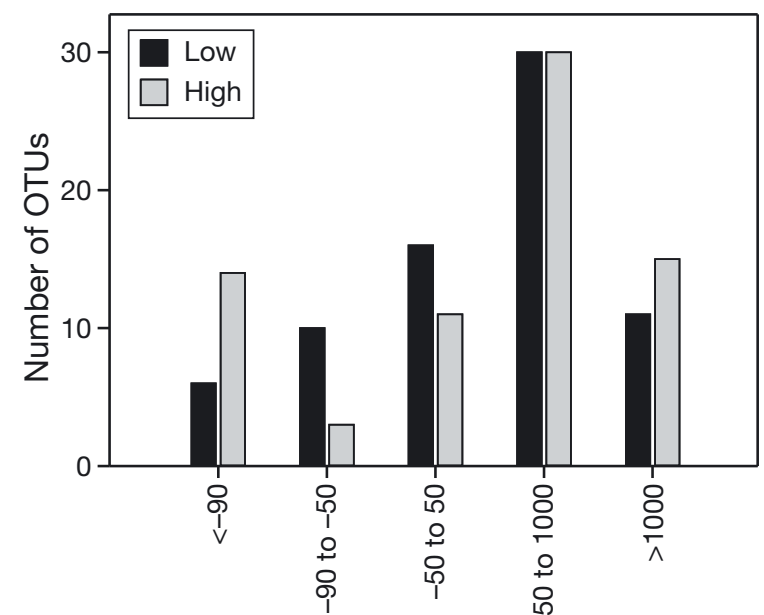

Change in relative abundance from $T_{0 \mathrm{~d}}$ to $T_{4 \mathrm{~d}}(\%)$

Fig. 7. Intervals of percentage change in relative abundance of aggregate-associated OTUs from $T_{0 \mathrm{~d}}$ to $T_{4 \mathrm{~d}}$ at either 15 or $70 \% \mathrm{O}_{2}$ AS (see the Supplement at www.int-res.com/ articles/suppl/a079p085_supp.pdf for heat maps of all 82 OTUs)

turnover of aggregate POC in the range of 2 to $11 \mathrm{~d}$ (Ploug \& Grossart 2000, Goldthwait et al. 2005). Therefore, the relatively constant rates of aerobic respiration and nitrate consumption observed in this study are remarkable, and indicate a steady supply of labile DOC that was sufficient to sustain constant microbial respiration for a total of $4 \mathrm{~d}$. However, the $\mathrm{O}_{2}$ consumption rates in the low $\mathrm{O}_{2}$ treatment were 2.8 times lower than in the high $\mathrm{O}_{2}$ treatment. As the $K_{\mathrm{m}}$ value for $\mathrm{O}_{2}$ of microbial $\mathrm{O}_{2}$ respiration is in the low micromolar to nanomolar range (Devol 1978, Tiano et al. 2014), $\mathrm{O}_{2}$ consumption rates are not expected to be affected substantially by a reduction of $\mathrm{O}_{2}$ levels from 70 to $15 \%$ AS. Potentially, solutes other than $\mathrm{NO}_{3}{ }^{-}$were reduced in the anoxic center of the aggregates. If the reduced solutes were not released to the surrounding water, or were only slowly reoxidized in the water, they may have contributed to the observed difference in $\mathrm{O}_{2}$ consumption. For instance, it has previously been found that model aggregate-associated $\mathrm{Fe}(\mathrm{III})$ reduction resulted in a net release of Fe(II) to the surrounding water (Balzano et al. 2009). The Fe(II) was only slowly reoxidized by the available $\mathrm{O}_{2}$, presumably due to, for example, adhesion to organic chelates (Balzano et al. 2009). Moreover, the difference presumably reflects a larger anoxic volume in the aggregate center at low ambient $\mathrm{O}_{2}$ levels, consistent with intensified dissimilatory nitrate reduction in these conditions. The reduced $\mathrm{O}_{2}$ consumption in the low $\mathrm{O}_{2}$ treatment also implies a slower turnover of labile organic carbon and hence a slower potential decay of activity at the reduced ambient $\mathrm{O}_{2}$ levels. The elevated consumption of $\mathrm{NO}_{3}{ }^{-}$in the low $\mathrm{O}_{2}$ treatment corresponds to $\sim 1 / 20$ of the difference in the $\mathrm{O}_{2}$ consumed at low vs. high ambient $\mathrm{O}_{2}$, and would only marginally have affected the organic carbon pool.

The higher ambient $\mathrm{O}_{2}$ availability in the high $\mathrm{O}_{2}$ treatment facilitated a more oxygenated interior of the aggregates and thereby enhanced the aggregateassociated labile organic carbon consumption. However, the production of $\mathrm{N}_{2}$ and the transient accumulation of $\mathrm{NO}_{2}{ }^{-}$imply that the centers of the aggregates were, in fact, still strongly depleted in $\mathrm{O}_{2}$, especially during the initial stages of the high ambient $\mathrm{O}_{2}$. The production of $\mathrm{N}_{2}$ and $\mathrm{NO}_{2}{ }^{-}$at high $\mathrm{O}_{2}$ declined from Day 1 and ceased at Day 4 (Fig. 3C,D), presumably as the volume with strong $\mathrm{O}_{2}$ depletion diminished along with the declining pool of labile DOC.

While we did not document anoxia in the aggregates directly, previous $\mathrm{O}_{2}$ microsensor measurements of the $\mathrm{O}_{2}$ distribution demonstrated internal anoxia in sinking phycodetrital aggregates; Skeletonema marinoi model aggregates, similar to the ones investigated here, exhibited completely anoxic centers at 15 and $40 \% \mathrm{O}_{2} \mathrm{AS}$, while centers were 
hypoxic $\left(\sim 100 \mu \mathrm{M} \mathrm{O}_{2}\right)$ at an ambient $\mathrm{O}_{2}$ level corresponding to $70 \%$ AS (Stief et al. 2016). In large natural cyanobacterial aggregates $(\varnothing \approx 4.7 \mathrm{~mm})$, the anoxic center expanded from 5 to $95 \%$ of the aggregate volume when the ambient $\mathrm{O}_{2}$ AS level was decreased from 100 to $30 \%$ (Klawonn et al. 2015).

The present study shows that diatom aggregates may support $\mathrm{NO}_{3}{ }^{-}$reduction and denitrification even at $70 \% \mathrm{AS}$, but also that strongly $\mathrm{O}_{2}$-depleted conditions in the aggregate interior, which are required to support these processes, were presumably only ephemeral at high ambient $\mathrm{O}_{2}$ levels. In contrast, strongly $\mathrm{O}_{2}$-depleted or anoxic conditions prevailed for all $4 \mathrm{~d}$ at low ambient $\mathrm{O}_{2}$ levels. The observations clearly confirm that intense internal anaerobic $\mathrm{N}$ cycling occurs in such aggregates and that the net activity represents a sink for bioavailable nitrogen, but also a source of $\mathrm{NO}_{2}^{-}$.

\section{Anaerobic $\mathbf{N}$ cycling in sinking and aging diatom aggregates}

Denitrification was the dominant pathway of dissimilatory nitrate reduction. We exclude a significant contribution from anammox based on the isotope pairing in ${ }^{15} \mathrm{~N}$-labeled $\mathrm{N}_{2}$, with ${ }^{30} \mathrm{~N}_{2}$ rather than ${ }^{29} \mathrm{~N}_{2}$ being the main gaseous product, and because populations of anammox bacteria are not expected to be able to establish in relatively short experiments, being obligate anaerobes and having notoriously low growth rates (Strous et al. 1999). In contrast, denitrifiers are typically facultative anaerobes, fast growing, and can change metabolism depending on the availability of $\mathrm{O}_{2}$ and $\mathrm{NO}_{3}{ }^{-}$(Zumft 1997). Dissimilatory $\mathrm{NO}_{3}{ }^{-}$reduction to $\mathrm{NH}_{4}{ }^{+}$(DNRA) was also not an important pathway as the ${ }^{15} \mathrm{NH}_{4}{ }^{+}$accumulation was negligible during the incubations. The significant release of $\mathrm{NO}_{2}{ }^{-}$, corresponding to $\sim 29$ and $41 \%$ of the $\mathrm{N}_{2}$ production in low and high $\mathrm{O}_{2}$ treatments, respectively, was intriguing. Many microbes are only able to perform dissimilative $\mathrm{NO}_{3}{ }^{-}$reduction to $\mathrm{NO}_{2}{ }^{-}$ (DNRN) and lack the ability to further reduce $\mathrm{NO}_{2}{ }^{-}$, and net production of $\mathrm{NO}_{2}^{-}$may simply reflect an uncoupling of $\mathrm{NO}_{3}^{-}$and $\mathrm{NO}_{2}{ }^{-}$reduction within the aggregate, as also observed in anoxic waters (Lam et al. 2009). The release of $\mathrm{NO}_{2}^{-}$from diatom aggregates could be an important biogeochemical feature of sinking aggregates, supplying free-living communities, for example of anammox bacteria, with $\mathrm{NO}_{2}{ }^{-}$, if aggregates sink through oxygen-depleted waters. Stief et al. (2016) also found high volume-specific $\mathrm{N}_{2}$ and $\mathrm{NO}_{2}{ }^{-}$production rates in diatom aggregates at
$15 \% \mathrm{O}_{2}$ AS. Klawonn et al. (2015) documented $\mathrm{N}_{2}$ production by relatively large cyanobacterial aggregates $(\varnothing \approx 4.7 \mathrm{~mm})$ at 30 and $100 \% \mathrm{O}_{2}$ AS, but the rates were more than an order of magnitude lower than measured here, with DNRA being the main pathway of dissimilatory $\mathrm{NO}_{3}{ }^{-}$reduction. S. marinoi cultures are able to perform DNRA under dark and anoxic conditions by reducing an accumulated intracellular storage of nitrate $\left(\mathrm{ICNO}_{3}{ }^{-}\right)$(Kamp et al. 2016). However, when associated with aggregates, $S$. marinoi apparently exhibits very low to negligible DNRA (Kamp et al. 2016). It rather appears that the lysis of aggregate-associated $S$. marinoi supplies the microbial community within the aggregates with $\mathrm{NO}_{3}{ }^{-} \cdot{ }^{28} \mathrm{~N}_{2}\left({ }^{14} \mathrm{~N}^{14} \mathrm{~N}\right)$ production accounted for 21 to $31 \%$ of total $\mathrm{N}_{2}$ production during the incubations, and isotope pairing calculations show that 8 to $13 \%$ of this ${ }^{28} \mathrm{~N}_{2}$ production cannot be explained from the ${ }^{14} \mathrm{NO}_{3}{ }^{-}$background concentration in the seawater. This fraction could represent an internal supply of ${ }^{14} \mathrm{NO}_{3}{ }^{-}$being released by the diatoms.

\section{Microbial colonization and succession in sinking and aging aggregates}

The majority of bacterial colonization of aggregates presumably takes place in the photic zone (Knoll et al. 2001, Kiørboe et al. 2003, Thiele et al. 2015 ) and little de novo colonization is anticipated to occur at greater depth (Thiele et al. 2015). However, aggregate-associated and free-living communities are shown to be fundamentally different, in both marine (DeLong et al. 1993, Rath et al. 1998, Moeseneder et al. 2001) and limnic (Crump et al. 1999, Allgaier \& Grossart 2006) settings. In our study, the aggregates were formed in surface water to mimic the natural microbial colonization process. However, when the aggregates were harvested for the incubations after $3 \mathrm{~d}$, the aggregate-associated bacterial communities were already different from the bacterial community in the ambient surface water (Fig. 6A, Table 1). This difference increased throughout the incubations, indicating further changes in the microbial community. Furthermore, the microbial communities within replicate aggregates became more similar with time. Therefore, time and, to a lesser extent, $\mathrm{O}_{2}$ seem to be strong selective forces with respect to microbial succession in our incubations. The influence of $\mathrm{O}_{2}$ becomes especially clear when considering the last 2 sampling time points $\left(T_{2 \mathrm{~d}}\right.$ and $\left.T_{4 \mathrm{~d}}\right)$, where the communities clustered with respect to not only time, but also $\mathrm{O}_{2}$ level (Fig. 6D). 
The unexpected finding that anaerobic $\mathrm{N}$ cycling in the low $\mathrm{O}_{2}$ treatment remained unaffected by the succession in the bacterial community within the aggregates indicates functional redundancy by the developing community. Considering that many different bacteria are capable of denitrification and DNRN (Tiedje 1988, Zumft 1997, Seitzinger et al. 2006), it is possible that changes in the amount and type of POC and DOC could diversify the internal microniches, but without affecting the overall rates of anaerobic $\mathrm{N}$ cycling.

The bacterial communities in the center and the outer layers of the aggregates could also exhibit different patterns of development. An indication for such differences is that, besides time, also the level of $\mathrm{O}_{2}$ drove the microbial succession in our study (Fig. 6D). Generally, the same OTUs demonstrated the most extreme changes at both high and low $\mathrm{O}_{2}$, but they were, surprisingly, more pronounced at high $\mathrm{O}_{2}$ (Fig. 7; see Fig. S2 in the Supplement at www.intres.com/articles/suppl/a079p085_supp.pdf). Here, a larger part of the outer layer of the aggregate remained oxic, leading to a higher carbon oxidation rate and a more pronounced selection for bacterial taxa capable of capitalizing energy from a range of organics, including both labile and more refractory material. Species belonging to the Cytophaga/Flavobacteria cluster and the Gammaproteobacteria are likely candidates, as they are shown to be among the dominant particle- and aggregate-associated bacteria (Ploug et al. 1999, Grossart et al. 2005, Balzano et al. 2009, Simon et al. 2014) and to increase their abundance over time in aggregates (Grossart \& Ploug 2000).

\section{Characteristics of the model aggregates}

Most experimental studies on marine snow have been performed on artificially produced aggregates (model aggregates), providing standard material for manipulative investigations. However, the characteristics of both model aggregates and in situ aggregates vary considerably among studies and can challenge cross-study comparisons as well as extrapolation to natural conditions. In Table 2, we have compiled relevant information on model and in situ phycodetrital aggregates from a range of different studies and environments.

Overall, investigated phycodetrital model aggregates have diameters ranging from 1.5 to $>20 \mathrm{~mm}$ and sinking speeds that span 45 to $1055 \mathrm{~m} \mathrm{~d}^{-1}$, with

Table 2. Key characteristics of phycodetrital aggregates as presented or derived from in situ and model studies. See the original articles for SD or SE. ESD, equivalent spherical diameter. -: key characteristic was not specified

\begin{tabular}{|c|c|c|c|c|c|c|}
\hline $\begin{array}{l}\text { Aggregate } \\
\text { constituents }\end{array}$ & $\begin{array}{c}\text { Size } \\
\text { (diameter; } \\
\mathrm{mm} \text { ) }\end{array}$ & $\begin{array}{c}\text { Size } \\
\text { (volume; } \\
\mathrm{mm}^{3} \text { ) }\end{array}$ & $\begin{array}{l}\text { Sinking } \\
\text { speed } \\
\left(\mathrm{m} \mathrm{d}^{1}\right)\end{array}$ & $\begin{array}{l}\text { Excess } \\
\text { density } \\
\left(\mu \mathrm{g} \mathrm{cm}^{3}\right)\end{array}$ & $\begin{array}{c}\text { C:N } \\
\text { (molar) } \\
-\end{array}$ & Reference \\
\hline \multicolumn{7}{|l|}{ Marine model aggregates } \\
\hline Diatoms & $2.2 \times 1.6 \times 1.6$ & 3.1 & 374 & 2.6 & 7.3 & This study \\
\hline Diatoms & $6.1 \times 4.0 \times 3.0$ & 42 & 1055 & - & - & Stief et al. (2016) \\
\hline Diatoms & $2.0-2.9$ (ESD) & $6.3-12.5$ & $59-117$ & - & $6.4-8.2$ & Ploug \& Bergkvist (2015) \\
\hline Diatoms and resuspended fluff particles & es $\quad 1.0-2.4$ & - & 518.4 & - & $9.3^{\mathrm{a}}$ & Ziervogel \& Forster (2005) \\
\hline Diatoms & $1-7$ (ESD) & - & $<750$ & $<6.5$ & $4.5^{\mathrm{a}}$ & Iversen \& Ploug (2013) \\
\hline Diatoms & 2.5 (ESD) & & 113 & $0.2-10$ & - & Iversen \& Ploug (2010) \\
\hline Diatoms & $2.6-5.9$ & - & $45-170$ & - & - & Ploug (2001) \\
\hline Diatoms & - & $1-40$ & $50-172$ & - & 7.7 & Ploug \& Grossart (2000) \\
\hline Diatoms & 20 (ESD, max. value) & - & - & - & - & Grossart et al. (2006) \\
\hline \multicolumn{7}{|l|}{ Marine in situ aggregates } \\
\hline Nodularia spumigena (cyanobacteria) & 4.7 & 60 & - & - & 4.6 & Klawonn et al. (2015) \\
\hline Diatom dominated & $1.6-9.5$ & - & $50-180$ & - & - & Ploug (2001) \\
\hline Diatom dominated & - & 3.4 and 247.0 & - & - & 12.3 and 12.4 & Grossart et al. (2003) \\
\hline Diatom dominated & - & $0.7-600$ & - & - & $6.5-8.5^{\mathrm{a}}$ & Alldredge (1998) \\
\hline Diatom dominated & $2.4-7.5$ & - & 74 & $0.01-22.00$ & - & Alldredge \& Gotschalk (1988) \\
\hline \multicolumn{7}{|l|}{ In situ sea-ice aggregates } \\
\hline Pennate diatom dominated & $10-150$ & - & - & - & $8-35$ & Fernández-Méndez et al. (2014) \\
\hline Melosira filaments & $10-300$ & - & - & - & $9-40$ & Fernández-Méndez et al. (2014) \\
\hline Pennate diatom dominated & $8.7-10.4$ & - & - & - & $8-11^{a}$ & Assmy et al. (2013) \\
\hline
\end{tabular}


the majority of the sizes and sinking speeds in the low to intermediary range (Table 2 ). When considering large aggregates formed below melting sea ice, the size range of in situ phycodetrital aggregates tends to be larger than model aggregates (Table 2). However, the sinking speeds of natural aggregates, 50 to $180 \mathrm{~m} \mathrm{~d}^{-1}$, tend to be lower than those of model aggregates, presumably due to less compaction of the associated biomass (Table 2). Nonetheless, studies report deposited fresh aggregates/diatom material at depths to $>4000 \mathrm{~m}$, arguing for fast sinking speeds of natural aggregates (Pfannkuche 1993, Boetius et al. 2013, Oguri et al. 2013). For instance, Agusti et al. (2015) estimated that to deliver the amount of living diatom cells observed at $3000 \mathrm{~m}$ depth, the sinking speed of natural aggregates needs to be 208 to $732 \mathrm{~m} \mathrm{~d}^{-1}$.

The C:N ratio of model aggregates generally ranges between 4.5 and 9.3 (Table 2). For natural aggregates, the variation is larger, from 4.6 and to up to 40 (Table 2), reflecting a high degree of variation in the organic material forming natural aggregates, and in some cases, contributions of more refractory, $\mathrm{N}$-depleted material.

The size, sinking speed, and C: $\mathrm{N}$ ratio of the model aggregates used in the present study are generally comparable to the values of model aggregates from previous investigations, but are also within the reported ranges of many in situ aggregates. It should, however, be acknowledged that given the relatively few in situ investigations on aggregates, it remains an open question to what extent the reported values reflect the actual range or even the average characteristics of aggregates in the vast, global ocean.

The present model study contributes to the previous finding that sinking $S$. marinoi aggregates can be sinks for bioavailable $\mathrm{N}$ and sources of $\mathrm{NO}_{2}^{-}$. It demonstrates that the anaerobic processes may even be active, albeit ephemeral, at high ambient oxygen, and we show, for the first time, that the activity can be sustained for several days at low ambient oxygen levels. These findings further strengthen the hypothesis that diatom aggregates play an integral and important role for pelagic $\mathrm{N}$ cycling, especially in $\mathrm{O}_{2}$ depleted environments where they may substantially contribute to $\mathrm{N}$ loss. However, natural aggregates are highly variable in size and composition, and they are exposed to changing environmental conditions during their descent. This is expected to affect their microbial community structure and their metabolic performance (DeLong et al. 2006, Nagata et al. 2010, Tamburini et al. 2013). Clearly, there is a need to investigate microbial processes in natural aggre- gates, but also to better accommodate and assess the importance of changing environmental drivers during aggregate descent, such as $\mathrm{O}_{2}$ availability, temperature, and hydrostatic pressure, which are expected to affect biogeochemical processing and microbial succession in phycodetrital aggregates.

Acknowledgements. This study was financially supported by the European Union's Horizon 2020 research and innovation programme (grant agreement no. 669947; HADESERC), and the Danish National Research Council (FNU; 0602-02276B). We thank A. Glud and D. H. Skov for technical support. Furthermore, U. Marzocchi and A. Kamp are acknowledged for useful discussions.

\section{LITERATURE CITED}

Agusti S, González-Gordillo JI, Vaqué D, Estrada M and others (2015) Ubiquitous healthy diatoms in the deep sea confirm deep carbon injection by the biological pump. Nat Commun 6:7608

Alldredge A (1998) The carbon, nitrogen and mass content of marine snow as a function of aggregate size. Deep-Sea Res A 45:529-541

Alldredge AL, Cohen Y (1987) Can microscale chemical patches persist in the sea? Microelectrode study of marine snow, fecal pellets. Science 235:689-691

Alldredge AL, Gotschalk C (1988) In situ settling behavior of marine snow. Limnol Oceanogr 33:339-351

Alldredge A, Youngbluth M (1985) The significance of macroscopic aggregates (marine snow) as sites for heterotrophic bacterial production in the mesopelagic zone of the subtropical Atlantic. Deep-Sea Res A 32: 1445-1456

Allgaier M, Grossart HP (2006) Seasonal dynamics and phylogenetic diversity of free-living and particle-associated bacterial communities in four lakes in northeastern Germany. Aquat Microb Ecol 45:115-128

*Anderson JJ, Okubo A, Robbins AS, Richards FA (1982) A model for nitrate distributions in oceanic oxygen minimum zones. Deep-Sea Res A 29:1113-1140

* Assmy P, Ehn JK, Fernández-Méndez M, Hop H and others (2013) Floating ice-algal aggregates below melting arctic sea ice. PLOS ONE 8:e76599

Azam F, Cho BC, Smith DC, Simon M (1990) Bacterial cycling of matter in the pelagic zone of aquatic ecosystems. In: Tilzer MM, Serruya C (eds) Large lakes. Springer, Berlin, p 477-488

Balzano S, Statham PJ, Pancost RD, Lloyd JR (2009) Role of microbial populations in the release of reduced iron to the water column from marine aggregates. Aquat Microb Ecol 54:291-303

Boetius A, Albrecht S, Bakker K, Bienhold C and others (2013) Export of algal biomass from the melting Arctic sea ice. Science 339:1430-1432

Bower CE, Holm-Hansen T (1980) A salicylate-hypochlorite method for determining ammonia in seawater. Can J Fish Aquat Sci 37:794-798

Braman RS, Hendrix SA (1989) Nanogram nitrite and nitrate determination in environmental and biological materials by vanadium(III) reduction with chemiluminescence detection. Anal Chem 61:2715-2718 
Codispoti LA, Brandes JA, Christensen JP, Devol AH, Naqvi SWA, Paerl HW, Yoshinari T (2001) The oceanic fixed nitrogen and nitrous oxide budgets: moving targets as we enter the anthropocene? Sci Mar 65:85-105

* Crump BC, Armbrust EV, Baross JA (1999) Phylogenetic analysis of particle-attached and free-living bacterial communities in the Columbia River, its estuary, and the adjacent coastal ocean. Appl Environ Microbiol 65:3192-3204

* Dalsgaard T, Thamdrup B, Farias L, Revsbech NP (2012) Anammox and denitrification in the oxygen minimum zone of the eastern South Pacific. Limnol Oceanogr 57: 1331-1346

DeLong EF, Franks DG, Alldredge AL (1993) Phylogenetic diversity of aggregate-attached vs. free-living marine bacterial assemblages. Limnol Oceanogr 38:924-934

DeLong EF, Preston CM, Mincer T, Rich V and others (2006) Community genomics among stratified microbial assemblages in the ocean's interior. Science 311:496-503

* Devol A (1978) Bacterial oxygen-uptake kinetics as related to biological processes in oxygen deficient zones of oceans. Deep-Sea Res 25:137-146

*Fernández-Méndez M, Wenzhöfer F, Peeken I, Sørensen HL, Glud RN, Boetius A (2014) Composition, buoyancy regulation and fate of ice algal aggregates in the central Arctic Ocean. PLOS ONE 9:e107452

Glud RN, Rysgaard S, Turner G, McGinnis DF, Leakey RJG (2014) Biological- and physical-induced oxygen dynamics in melting sea ice of the Fram Strait. Limnol Oceanogr 59:1097-1111

* Glud RN, Grossart HP, Larsen M, Tang KW and others (2015) Copepod carcasses as microbial hot spots for pelagic denitrification. Limnol Oceanogr 60:2026-2036

* Goldthwait SA, Carlson CA, Henderson GK, Alldredge AL (2005) Effects of physical fragmentation on remineralization of marine snow. Mar Ecol Prog Ser 305:59-65

Grossart HP, Ploug H (2000) Bacterial production and growth efficiencies: direct measurements on riverine aggregates. Limnol Oceanogr 45:436-445

Grossart HP, Ploug H (2001) Microbial degradation of organic carbon and nitrogen on diatom aggregates. Limnol Oceanogr 46:267-277

* Grossart HP, Hietanen S, Ploug H (2003) Microbial dynamics on diatom aggregates in Oresund, Denmark. Mar Ecol Prog Ser 249:69-78

* Grossart HP, Levold F, Allgaier M, Simon M, Brinkhoff T (2005) Marine diatom species harbour distinct bacterial communities. Environ Microbiol 7:860-873

Grossart HP, Czub G, Simon M (2006) Algae-bacteria interactions and their effects on aggregation and organic matter flux in the sea. Environ Microbiol 8:1074-1084

Iversen MH, Ploug H (2010) Ballast minerals and the sinking carbon flux in the ocean: carbon-specific respiration rates and sinking velocity of marine snow aggregates. Biogeosciences 7:2613-2624

Iversen MH, Ploug H (2013) Temperature effects on carbonspecific respiration rate and sinking velocity of diatom aggregates-potential implications for deep ocean export processes. Biogeosciences 10:4073-4085

Kamp A, de Beer D, Nitsch JL, Lavik G, Stief P (2011) Diatoms respire nitrate to survive dark and anoxic conditions. Proc Natl Acad Sci USA 108:5649-5654

Kamp A, Stief P, Bristow LA, Thamdrup B, Glud RN (2016) Intracellular nitrate of marine diatoms as a driver of anaerobic nitrogen cycling in sinking aggregates. Front Microbiol 7:1669
Kempers AJ, Kok CJ (1989) Re-examination of the determination of ammonium as the indophenol blue complex using salicylate. Anal Chim Acta 221:147-155

*Kiørboe T, Tang K, Grossart HP, Ploug H (2003) Dynamics of microbial communities on marine snow aggregates: colonization, growth, detachment, and grazing mortality of attached bacteria. Appl Environ Microbiol 69: 3036-3047

Klawonn I, Bonaglia S, Bruchert V, Ploug H (2015) Aerobic and anaerobic nitrogen transformation processes in $\mathrm{N}_{2}$ fixing cyanobacterial aggregates. ISME J 9:1456-1466

* Knoll S, Zwisler W, Simon M (2001) Bacterial colonization of early stages of limnetic diatom microaggregates. Aquat Microb Ecol 25:141-150

*Lam P, Lavik G, Jensen MM, van de Vossenberg J and others (2009) Revising the nitrogen cycle in the Peruvian oxygen minimum zone. Proc Natl Acad Sci USA 106: 4752-4757

Kiu WT, Marsh TL, Cheng H, Forney LJ (1997) Characterization of microbial diversity by determining terminal restriction fragment length polymorphisms of genes encoding 16S rRNA. Appl Environ Microbiol 63: 4516-4522

* McIlvin MR, Altabet MA (2005) Chemical conversion of nitrate and nitrite to nitrous oxide for nitrogen and oxygen isotopic analysis in freshwater and seawater. Anal Chem 77:5589-5595

* Moeseneder MM, Winter C, Herndl GJ (2001) Horizontal and vertical complexity of attached and free-living bacteria of the eastern Mediterranean Sea, determined by 16S rDNA and 16S rRNA fingerprints. Limnol Oceanogr 46:95-107

*Nagata T, Tamburini C, Arístegui J, Baltar F and others (2010) Emerging concepts on microbial processes in the bathypelagic ocean-ecology, biogeochemistry, and genomics. Deep-Sea Res II 57:1519-1536

Nielsen LP (1992) Denitrification in sediment determined from nitrogen isotope pairing. FEMS Microbiol Ecol 86: $357-362$

* Oguri K, Kawamura K, Sakaguchi A, Toyofuku T and others (2013) Hadal disturbance in the Japan Trench induced by the 2011 Tohoku-Oki Earthquake. Sci Rep 3:1915

* Oksanen J, Blanchet FG, Kindt R, Legendre P and others (2013) Multivariate analysis of ecological communities in $\mathrm{R}$ : vegan tutorial. $\mathrm{R}$ package version 1.7. www. researchgate.net/publication/275524120_Multivariate_ analysis_of_ecological_communities_in_R_vegan_tutorial _R_package_version_17

Paerl HW, Bebout BM (1988) Direct measurement of $\mathrm{O}_{2}-$ depleted microzones in marine oscillatoria: relation to $\mathrm{N}_{2}$ fixation. Science 241:442-445

Pfannkuche O (1993) Benthic response to the sedimentation of particulate organic matter at the BIOTRANS station, $47^{\circ} \mathrm{N}, 20^{\circ} \mathrm{W}$. Deep-Sea Res II 40:135-149

* Ploug H (2001) Small-scale oxygen fluxes and remineralization in sinking aggregates. Limnol Oceanogr 46: 1624-1631

* Ploug H, Bergkvist J (2015) Oxygen diffusion limitation and ammonium production within sinking diatom aggregates under hypoxic and anoxic conditions. Mar Chem 176: 142-149

Ploug H, Grossart HP (2000) Bacterial growth and grazing on diatom aggregates: respiratory carbon turnover as a function of aggregate size and sinking velocity. Limnol Oceanogr 45:1467-1475 
Ploug H, Kühl M, Buchholz-Cleven B, Jørgensen BB (1997) Anoxic aggregates - an ephemeral phenomenon in the pelagic environment? Aquat Microb Ecol 13:285-294

Ploug H, Grossart H, Azam F, Jrgensen BB (1999) Photosynthesis, respiration, and carbon turnover in sinking marine snow from surface waters of Southern California Bight: implications for the carbon cycle in the ocean. Mar Ecol Prog Ser 179:1-11

Quinn GP, Keough MJ (2002) Experimental design and data analysis for biologists. Cambridge University Press, Cambridge

Rath J, Wu KY, Herndl GJ, DeLong EF (1998) High phylogenetic diversity in a marine-snow-associated bacterial assemblage. Aquat Microb Ecol 14:261-269

Schramm A, de Beer D, Wagner M, Amann R (1998) Identification and activities in situ of Nitrosospira and Nitrospira spp. as dominant populations in a nitrifying fluidized bed reactor. Appl Environ Microbiol 64: 3480-3485

Seitzinger S, Harrison JA, Böhlke JK, Bouwman AF and others (2006) Denitrification across landscapes and waterscapes: a synthesis. Ecol Appl 16:2064-2090

Silver M (2015) Marine snow: a brief historical sketch. Limnol Oceanogr Bull 24:5-10

* Simon H, Lipsewers YA, Giebel HA, Wiltshire KH, Simon M (2014) Temperature effects on aggregation during a spring diatom bloom. Limnol Oceanogr 59:2089-2100

Simon M, Grossart HP, Schweitzer B, Ploug H (2002) Microbial ecology of organic aggregates in aquatic ecosystems. Aquat Microb Ecol 28:175-211

Smetacek VS (1985) Role of sinking in diatom life-history cycles: ecological, evolutionary and geological significance. Mar Biol 84:239-251

Smith D, Simon M, Alldredge A, Azam F (1992) Intense hydrolytic enzyme-activity on marine aggregates and implications for rapid particle dissolution. Nature 359: 139-142

Stief P, Kamp A, Thamdrup B, Glud RN (2016) Anaerobic nitrogen turnover by sinking diatom aggregates at varying ambient oxygen levels. Front Microbiol 7:98
Strous M, Kuenen JG, Jetten MSM (1999) Key physiology of anaerobic ammonium oxidation. Appl Environ Microbiol 65:3248-3250

* Tamburini C, Boutrif M, Garel M, Colwell RR, Deming JW (2013) Prokaryotic responses to hydrostatic pressure in the ocean - a review. Environ Microbiol 15:1262-1274

* Thiele S, Fuchs BM, Amann R, Iversen MH (2015) Colonization in the photic zone and subsequent changes during sinking determine bacterial community composition in marine snow. Appl Environ Microbiol 81:1463-1471

Tiano L, Garcia-Robledo E, Dalsgaard T, Devol AH and others (2014) Oxygen distribution and aerobic respiration in the north and south eastern tropical Pacific oxygen minimum zones. Deep-Sea Res A 94:173-183

Tiedje JM (1988) Ecology of denitrification and dissimilatory nitrate reduction to ammonium. In: Zehnder AJB (ed) Environmental microbiology of anaerobes. John Wiley \& Sons, New York, NY, p 179-244

Velji MI, Albright LJ (1986) Microscopic enumeration of attached marine bacteria of seawater, marine sediment, fecal matter, and kelp blade samples following pyrophosphate and ultrasound treatments. Can J Microbiol 32:121-126

Warembourg FR (1993) Nitrogen fixation in soil and plant systems. In: Knowles R, Paul EA, Melillo J, Blackburn H (eds) Nitrogen isotope techniques. Academic Press, San Diego, CA, p 127-156

Wörner U, Zimmerman-Timm H, Kausch H (2000) Succession of protists on estuarine aggregates. Microb Ecol 40: 209-222

Yang F, Troncy E, Francœur M, Vinet B, Vinay P, Czaika G, Blaise $G$ (1997) Effects of reducing reagents and temperature on conversion of nitrite and nitrate to nitric oxide and detection of NO by chemiluminescence. Clin Chem 43:657-662

Ziervogel K, Forster S (2005) Aggregation and sinking behaviour of resuspended fluffy layer material. Cont Shelf Res 25:1853-1863

Zumft WG (1997) Cell biology and molecular basis of denitrification. Microbiol Mol Biol Rev 61:533-616

Submitted: October 12, 2016; Accepted: March 3, 2017

Proofs received from author(s): April 7, 2017
Editorial responsibility: Ilana Berman-Frank, Ramat Gan, Israel 